\title{
The Hunter's Trail: Poems by Wendell Berry
}

\author{
Kenneth Fields
}

And change with hurried hand has swept these scenes:

The woods have fallen, across the meadow-lot

The hunter's trail and trap-path is forgot,

And fire has drunk the swamps of evergreens ...

F. G. Tuckerman

Pound and Williams continue to be useful paradigms in our poetry: the one, an erudite antique collector who, after many expansions of shop, found himself with more curious merchandise than even he could inventory; the other, a provincial dealer in small pieces of Americana, a few of them perfect, but the rest easily duplicated. Pound shows the legacy of the Symbolist movement, for, like so many of its other inheritors, he writes poems which are intended not to be read but to be explicated. Language, one feels while reading him, is arcane and, save for flashes of suggested meaning, opaque to all but the most devoted researchers. Williams, on the other hand, believed that "the particles of language must be clear as sand," and his poems are illustrations of the theory. The best of them are written in plain, conventional language, and though they are not ultimately for the man on the street, it's plain that he would be able to get through them, often with pleasure. It's important to keep these two types in mind while reading modern poets, and to be aware that there are two. Reading a poem by someone like Robinson for the first time, I would almost certainly not understand it completely, but I would recognize it as understandable. Whereas after reading someone like Crane for the first time, I might say, "Not only do I fail to understand this poem completely, I don't understand it at all." But (and this perhaps only because I am an academic) I might declare it to be figurable. Figurable and Understandable poets are still with us, some of them as friendly to each other as were Pound and Williams: Robert Duncan and Denise Levertov, and Charles Olson and Robert Creeley, though far declined from their masters, are obvious examples.

Wendell Berry (b. 1934) is an Understandable poet, and a good one. I can give no better example of his distance from much of what is fashionable than an exchange I overheard between Berry and a friend who wrote surrealist poems. The subject was teaching the writing of poetry. The friend said that his students did their writing in class, automatically, without reflection and without trying to make sense. He added that they often needed "inspiration" and, as an example, he told how he had once brought into the classroom a dressmaker's dummy and, placing a beercan on its head, had merely told his students, "Write!" It is typical that Berry did not comment directly, but instead gave his own example. 
"When I taught at NYU," he quietly replied, "I used to take kids who had grown up in the city to a park and ask them to write about a tree or some flowers." Without much time for reflection, the surrealist objected, "Naw, you've got to give them something unusual, something that shocks them-like a boxing glove and a piece of raw liver." Hanging fire just for a moment, or so I saw it as an outsider, Berry in his modest way changed the subject.

Plainly a man at work who loves to write, Berry seems to have natural good taste: and rarest of all, he seems to be an author for whom writing comes easily. Perhaps a little too easily, for in some ways he has been willing to publish too much. He has written two novels, Nathan Coulter (1960), and A Place on Earth (1967), a book of essays, The Long-Legged House (1969), and three books of poetry, The Broken Ground (1964), Findings (1969), and, though published earlier than Findings, his latest book, Openings (1968). Farming: A Handbook, most of which I have seen in manuscript, should appear shortly. This comes to seven books in nine years. His best work is plain and deals with the things closest to him: the Kentucky landscape, a few of its inhabitants, and his wife. Fine as they are, however, the best poems were a long time coming.

The subject and style of The Broken Ground purport to be plain, and two of the best poems, "The Apple Tree" and "May Song," show the influence of Williams. But the book is often curiously labored and even ornate, and the style comports oddly with the simplicity of the subjects. Consider these lines:

Until morning comes say of the blind bird:

His feet are netted with darkness, or he flies

His heart's distance into the darkness of his eyes.

A season's sun will light him no tree green.

Or these:

The river clears after the winter

floods; the slopes of the hills renew

the sun, diaphanous flower and leaf, blue-green

with distance, patina of their substantial

bronze. . .

"The blind bird, heart's distance into the darkness of his eyes," "no tree green," "diaphanous flower and leaf," "patina of their substantial bronze"-here, the poet may be standing on the broken ground, but the quality of his perceptions, that is to say, his language, is that of a self-conscious literary man, and he writes in clichés. Occasionally, one gets extraordinary details, as in the second part of "The River Voyagers," or these lines from "Diagon," reminiscent of Hérédia, in which the floridity is a part of the strangeness of the description:

By night the great fish

Hunt the shallows, their silent breathing

Opening red flowers of their gills. 
In these lines, and in poems like "the child born dead," "Sparrow" and "The Wild," we can see promises of poems to come.

The ornateness of the first book disappears in Findings, a very curious piece of work. Consisting largely of poem-sequences, it strikes me as the work of a talented novelist. Only occasionally does a whole poem come off successfully, though scattered through the book are several excellent passages, such as the following one, describing the conversation of an eighty-year-old grandfather and his grandson:

The quietness of knowing in common is half of it. Silences come into it easily, and break it

while the old man thinks or concentrates on his pipe and the strong smoke

climbs over the brim of his hat.

$\mathrm{He}$ has lived a long time.

He has seen the changes of times

and grown used to the world again. Having been wakeful so long, the loser of so many years,

his mind moves back and forth, sorting and counting, among all he knows.

His memory has become huge and surrounds him, and fills his silences.

Perhaps the description ought to have its place in a story or a novel, but the writing is genuine and, in contrast to the first book, unpretentious. He has the low-keyed tone of ordinary life, the studied leisure of prose. The chief trouble with the book is its prolixity: he uses too many words, often diminishing his effects. Even the passage just quoted is marred by the redundancy and flatness of "He has lived a long time." The fault appears again and again. Who, save aficionados of Eliot, will read lines like these without exasperation?-

[The dead] went out like fires

that burn into recollection, consuming memory also, and the memories of memory and the rememberers also. 
A final example should make my objections to the book clear. Here are three lines, about an old man near death, which are sharp in themselves and moving, especially the phrase, "fading script":

His garden rows go back through all

his summers, bearing their fading

script of vine and bloom. .

But in its context the fine edge of his perception is blunted by redundancy:

His life has been a monument to the place.

His garden rows go back through all

his summers, bearing their fading

script of vine and bloom,

what he has written on the ground,

its kind abundance, taken kindly from it.

This is simply easy writing, and it is a pity that Berry did not know when to stop. Most of the second section, for example, does little more than set up part two of "An Epilogue."

Openings, however, is another matter: it is far and away his best book. Here, he is on solid ground, and he gives us several whole poems, the fulfilled promises of his earlier work.

As we learn from his interesting collection of essays, The Long-Legged House, Berry had spent several years away from Kentucky, and finally decided to leave the Eastern literary and academic world to return to his birthplace. "As a writer, then, I have had this place as my fate," he tells us, and the essays make it clear that he has scarcely chosen his subject; instead, it has chosen him. The small rural area near Port Royal, with its myriads of details, has a power over him that is close to being an obsession. Now no longer a self-conscious interloper, or a man coming home for vacations, Berry is home to stay. In Openings he moves easily through his woods as a native hunter, sure of his footing and of his language.

And for the first time, really, we see him using the language of a poet. We can give poetry its simplist definition by saying that it is "language written in lines," and to my eye and ear Berry only occasionally uses the line well in his early poems. But notice his control in "The Finches," as he lets the turns of his short line place the emphasis exactly. We know how the sentences sound by the ways in which the syntax runs across line and stanza endings: "comes / the song," "bright, then / dark," "they move into / and then against the light." And the rhythms of the second half of the poem are even more effective.

The ears stung with cold

sun and frost of dawn

in early April, comes 
the song of winter finches, their crimson bright, then dark as they move into

and then against the light. May the year warm them soon. May they soon go

north with their singing and the season follow.

May the bare sticks soon

live, and our minds go free of the ground into the shining of trees.

He is usually strongest when his poems are descriptive, with a minimum of commentary, for his mind deals much better with the concrete than with the abstract. Throughout his work one feels that his mind moves with the seasons; in fact his mind seems to be dominated by them. He is like Yoshinobu's deer, startled and moved by the season:

The deer which lives

On the evergreen mountain

Where there are no autumn-leaves

Can know the coming of autumn

Only by its own cry.

(trans. Arthur Waley)

In a sense Berry is the entranced captive of process, and while for me his captivity restricts his range, it nevertheless results in considerable beauties. Two passages from his prose resemble "The Finches" in tone and feeling:

On the tenth of April, I woke at about six o'clock, and the first sound I heard was the song of the sycamore warbler, returned from the South. With that my thoughts entered spring. I went into the woods and found the bloodroot in bloom.

Describing the end of March:

It is still winter, and my thoughts keep their winter habits. But soon there will come a day when, without expecting to, I will hear the clear seven-note song of the sycamore warbler passing over the Camp roof. Something will close and open in my mind like a page turning. It will be another spring. 
Lovely as the passages are, "The Finches" is better, mainly because of the verse rhythms. Let us go back to the poem for a moment. He is anxious for his mind to put aside its winter habits-of numbness, barrenness, lack of sensation--and to move into the new season as naturally as the "bare sticks" put out new leaves. This anxiety is rendered by the repeated subjunctive wish for the sensations of warmth, color, movement, and sound, for the variety of spring; and the repeated subjunctive gives us an effective pun on the desired season, May. Moreover, the repetition of "soon," in conjunction with the run-on lines, italicizes his urgency: "May the year warm them / soon. May they soon go / north . . . May the bare sticks soon / live. Compare his grace with Bryant's, to whom Berry may be a little in debt; from "To A Waterfowl":

And soon that toil shall end;

Soon shalt thou find a summer home, and rest,

And scream among thy fellows; reeds shall bend,

Soon, o'er thy sheltered nest.

"The civilized people have lost the aptitude of stillness," Isak Dinesen writes in Out of Africa,
and must take lessons in silence from the wild before they
are accepted by it. The art of moving gently, without
suddenness, is the first to be studied by the hunter, and more so by the hunter with the camera. Hunters cannot have their own way, they must fall in with the wind, and the colours and smells of the landscape, and they must make the tempo of the ensemble their own.

This close harmony with nature, for Berry, is clearly a condition of grace. But whereas in even the best of his essays (I think of "A Native Hill") there are passages that go soft because of a melodramatic treatment of the religion of nature, many of his poems treat the subject modestly and effectively. A regional neighbor, James Dickey the ex-football player and flyer, is obsessed with power, as Robert Bly has observed. Dickey seeks either to dominate or, in the extremities of defeat, to be dominated-his surrender is the renunciation of living. If obscurely voluntaristic, Berry's position, in contrast, is humane, a way of beginning, not of concluding; neither winning nor losing, he simply coexists. In perhaps his best poem he moves toward the quotation of his friend, lovely in itself, with remarkable sureness.

$$
\begin{aligned}
& \text { Grace } \\
& \text { for Gruney Norman, quoting him }
\end{aligned}
$$

The woods is shining this morning.

Red, gold and green, the leaves

lie on the ground, or fall,

or hang full of light in the air still.

Perfect in its rise and in its fall, it takes 
the place it has been coming to forever.

It has not hastened here, or lagged.

See how surely it has sought itself,

its roots passing lordly through the earth.

See how without confusion it is

all that it is, and how flawless

its grace is. Running or walking, the way

is the same. Be still. Be still.

"He moves your bones, and the way is clear."

Thus, the naturalness of life. And, as for death:

\section{The Burial of the Old}

The old, whose bodies encrust their lives, die, and that is well.

They unhinder what has struggled in them.

The light, painfully loved, that narrowed and darkened in their minds becomes again the sky.

The young, who have looked on dying, turn back to the world, grown strangely alert to each other's bodies.

In the essays and poems he watches nature, chiefly that of Port Royal, with love and fascination; and he watches mankind with weariness and disappointment, plainly aware of the dangers of this situation. "Window Poems," a sequence of 27 poems, interesting in themselves, but too close to a journal, too crowded with necessary but flat or prosaic details, states his persistent themes. In need of editing, the sequence still contains some splendid passages. From the window of his study, beautifully photographed on the dust wrapper of Openings, the poet watches the animals and trees of his farm, always feeling in his bones the "strong god," the river, that moves through all of his books. Like Frost, say, in "The Last Mowing," Berry seems fascinated by chaos, but he is also ashamed at the thought that "the earth might be better without men":

there will be the second coming

of the trees. They will come

straggling over the fences

slowly, but soon enough.

The highways will sound

with the feet of the wild herds,

returning. Beaver will ascend

the streams as the trees

close over them. 
Although one may ultimately object to the sentiment, it is fully understandable beneath the weight of much of the world today. Nor does Berry, from his retreat, ignore the world. In the "Window" sequence he realizes that finally he cannot remain in his study but must venture into the open, and in The Long-Legged House he takes up such various and public subjects as the unconscious American impulse to destroy the wilderness into which we go for our leisure, the ruinousness of strip mining in Kentucky, and the war in Vietnam-all with a common theme:

Man cannot be independent of nature. In one way or another he must live in relation to it, and there are only two alternatives: the way of the frontiersman, whose response to nature was to dominate it, to assert his presence in it by destroying it; or the way of Thoreau, who went to the natural places to become quiet in them, to learn from them, to be restored by them.

It is clear, as one reads through his books, that his private reverence for nature, for the living, underlies his public disgust for man's willingness to violate life in the interests of generalities. The men who destroy Kentucky with efficient but ruthless mining technology, the men who travel along its rivers by speedboat, strewing "more rubbish in one night than all the Shawnees made," and the men who kill peasants in Vietnam and West Virginia, Berry implies, are all of the same flesh, all suffering from the same disease. As I watch the evening news on television, I am inclined to agree. My enthusiasm at our having put two men on the moon was as great as the next man's; and, unlike the wives of the astronauts, I could indeed believe it: with our extraordinary technicians in command, 24 billion dollars will obviously go a long way. But my enthusiasm wanes a little when in the same year we must tighten our federal supporter by cutting from the budget a few millions that would aid the American Indians, perhaps our most disadvantaged minority group. Michael Harrington has called ours the "accidental century," and aptly. How could Ford have known that the automobile would cause so many deaths, and would pollute our air and force us to cover so much of our land with cement? And he never could have foreseen the willful ignorance that permitted Union Oil to ruin the beaches of Santa Barbara, one of our loveliest cities, and continue to drill more wells.

Berry's essays excoriate the separation of private from public morality, and rightly so, but it is true that his best poems deal with his private, or at least his personal and vivid experience. Earlier I suggested his similarity to a greater poet, W. C. Bryant. Bryant had the eye of a hunter and knew as well as any poet how to turn a line:

Myriads of insects, gaudy as the flowers

They flutter over, gentle quadrupeds,

And birds, that scarce have learned the fear of man,

Are here, and sliding reptiles of the ground, 
Startlingly beautiful. The graceful deer

Bounds to the wood at my approach.

But Bryant cannot escape moralizing: it is almost as if he has two kinds of diction, the one "poetical" or descriptive, the other, didactic, in which he presents his ideas: the first class of diction being personal, the second being public. The same dichotomy marks Berry's poems. We have seen his descriptive poems, and I prefer them to nearly all of the fashionable poetry that comes my way.

But Berry, a moral man, wants to treat public subjects, and when he does his voice fails him. He does not have the language of Yvor Winters in "Before Disaster," "The Prince," or "Moonlight Alert"; nor does he have Hardy's in his "On The Belgian Expatriation." "Dark With Power" is his best Vietnam poem, but his best political statements come from his prose, especially the essays "The Landscaping of Hell," "A Statement Against the War in Vietnam," and "Some Thoughts on Citizenship and Conscience." His public poems are another matter. These lines are typical:

Believe in the automatic righteousness

of whoever holds an office. Believe

the officials who see without doubt

that peace is assured by war.

Or, the first lines from a poem published in the Tennessee Poetry Journal, "The Morning's News":

To moralize the state, they drag out a man, and bind his hands, and darken his eyes with a black rag to be free of the light in them, and tie him to a post, and kill him.

I entirely agree with the sentiments, and they are noble. But genuine as the feelings may be, the language is that of the public media. Clichés, like all bad poetry, as Oscar Wilde, an authority on the subject, has said, spring from genuine sentiments. When Berry has undertaken public issues in verse he has done so as a journalist.

Perhaps I have not fully represented all of Berry's subjects in my quotations. Notable omissions are the poems to his wife-"Marriage" and "A Poem of Thanks" being two of the best. And there are others in his forthcoming collection, the best of which is one called, as I remember, "Air and Fire." Nevertheless, when one takes his ideas and all of his work into account, one must remark certain limitations. $\mathrm{He}$ is almost an obsessed man, and has fewer subjects and, as important, fewer kinds of rhythm than he ought. Consequently much of his poetry is tonally all of a piece. Anyone who has read through his books will know the limitations of his concerns, and I have dwelt on some of them in this essay. On the other hand, the poems I have quoted are solid and whole, they are clear examples of his talent. No poet who is still writing likes to hear this: but to have written five or six solid poems is all that any poet, save a few of our finest, ought to expect, though 
one always keeps trying for more. From what I have seen of the forthcoming book, Farming, I think that we will have more good poems from Wendell Berry. During the current year, as I understand it, he will undertake subsistence farming, living on what he himself raises; and he will write about this experience. Nevertheless, the project is fraught with danger. The effects are getting repetitive: planting, the rains, the birds, and the river are eventually exhausted as subjects. "To see the woods from the inside," he has written, "one must look and move and look again. It is inexhaustible in its standpoints. A lifetime will not be enough to experience it all." As a description of a certain way of life the statement is true, but it is a limited and limiting way of developing new subjects. Openings is a fine book, but I think that Berry is going to have to find new things to write about in the future. Unlike most of his contemporaries, though, he is worth waiting for. 